\title{
Analysis on the current situation of University Library Service under MOOC environment
}

\author{
Haiyan LIU ${ }^{1, a}$ \\ ${ }^{1}$ Information Technology Institute of Jilin Agricultural University, Changchun, CHINA \\ ahaiyan_49@sohu.com
}

Keywords: University Library; MOOC services; Present situation; Librarian Service

\begin{abstract}
In order to better fulfill their functions and meet the needs of users and achieve coordinated development with MOOC, university library should actively carry out MOOC services. At present, only a handful of Academic Libraries in our country have carried out MOOC services, and its service content focuses on the support of the MOOC curriculum. In this paper, we first analyze the important influence of the higher education. The ways of improving the service of library are discussed which are combined with some examples of foreign libraries. How librarians provide services to support MOOC. Finally put forward the corresponding suggestions.
\end{abstract}

\section{Introduction}

MOOC (Massive online open Courses) is an online course that features free and open enrollment, curriculum sharing, and open output.It integrates social networks and online resources. In this way, it is an important basis for the learners to participate in their own activities, which are based on the learning objectives, the existing knowledge skills and the common interest[1].

MOOC caused widespread concern in the academic circle and the public in 2011.In this case, the University Library as a teaching and learning institutions need to fully understand the MOOC and prepare and play a positive role.This paper first summarizes the significance of MOOC to higher education and colleges and universitiesand puts forward the corresponding suggestionsIn order to give some enlightenment to the service innovation of University Library.

\section{The significance of MOOC to higher education}

\section{Promote global education resource sharing}

MOOC has become global public goods to promote the sharing of educational resources and the democratization of educationin higher education.

Learners around the world are no longer subject to geographical, nationality, age, class and economic conditions. They have equal access to school and enjoy the same educational content and form.Global MOOC providers are committed to promoting educational resources sharing, to improve the quality of the public access to high quality courses.

\section{Effectively reduce the cost of Education}

The expenditure of higher education is increasing year by year, and the universities are faced with the enormous pressure to create and deliver value. MOOC is considered to be able to effectively control costs and make up the "skills gap" means. MOOC can attract more students to effectively study the teaching quality and expand the influence of the school for colleges and universities.MOOC network teaching can save money. There have been MOOC charges, which can be regarded as a way to increase the income of colleges and universities.For learners, there is almost no threshold limit for learning the curriculum. Learners can choose professional subjects to improve their skills according to the actual needs. Learning time is flexible, and the cost of learning is relatively small.

\section{Promote the reform of Higher Education}

Although the network and distance education has already appeared, it is often regarded as a supplement to the traditional education mode, and there is no breakthrough significance.MOOC has changed the concept of "Curriculum" and "student" in the traditional concept, and has changed the 
communication and interaction in the teaching process.Under its influence, the world's major colleges and universities will not only launch a large number of high quality and highly interactive online courses, but also to maximize the advantages of MOOC.In order to achieve a better learning effect, colleges and universities adjust and improve the traditional curriculum.

\section{The influence of MOOC on University Library}

The vigorous development of MOOC has made a series of changes in the service concept, service object, service model, resource construction, space development and so on. The university library is facing the unprecedented challenge [2]. The impact of MOOC on the higher education makes the university library may no longer be needed and the support ability of university library is not enough. MOOC gives the new information service content and service mode of the library, For example, information literacy education, subject services, embedded services, copyright services, information sharing services, etc. It provides a new stage for the service innovation of the library [3].

\section{Analysis on the role of University Librarians}

\section{MOOC course provider}

Library is responsible for the teaching and training of information literacy in schools. This also means that a considerable number of university librarians are playing the role of teaching. Even a part of the library will be set up with literature and teaching and research section, as well as equipped with a full-time retrieval course teacher. School of information management, Wuhan University, Wuhan yellow flower professors lecture "information retrieval" course from September 2014 in China University MOOC on-line now, has opened three times, the number of learning more than 4 million people. Information literacy teaching MOOC courses are very popular. During the 2014 to 2015 period of the provincial quality project, there have been a number of MOOC courses offered by the library teacher in Anhui Province. Therefore, librarians should actively try to set up MOOC courses in the field of their own good to play their own value, and become the provider of MOOC courses.

\section{MOOC theory researchers}

At present, the domestic scholars have a lot of research on MOOC. The author uses "/MOOCS MOOC/" in the CNKI to carry on the subject search. There are 4150 papers. Among them, only 293 articles were related to the library. The focus of the article for in under MOOC library service of and for theoretical discussion, lack of resources construction and platform support of research, theory and practice of combining research content too few. MOOC is currently a hot topic, but the library and MOOC related discussion is not sufficient. University librarians as the main body of university library should strive to explore, actively practice, carry out MOOC related research work, and explore the way to adapt to the development of MOOC library.

\section{Supporters of MOOC construction}

More and more universities and teachers are willing to try this new teaching mode with the gradual popularization of MOOC. In the quality of the project in Anhui Province, there were 107 courses about MOOC in 2014. In 2015, the figure rose to 227[4]. University librarians need to think about how to better provide support for these MOOC courses, and promote the development of school MOOC construction work. The author believes that the librarians can start from the following three aspects.

1. MOOC related resources support. University librarians should take an active part in the planning and design of the MOOC curriculum in schools and collect the relevant network curriculum resources of MOOC [5]. They also focus on the school MOOC production of the teacher's specific curriculum needs, and set the curriculum related knowledge content and reference materials, as well as provide curriculum background information retrieval and screening.

2. MOOC platform support. MOOC courses need is released through the platform that can be directly using the MOOC platform from at home and abroad. The librarians act as the role of a 
bridge for cooperation between the two threading a needle. Because of MOOC itself on the platform of higher technical requirements, more colleges and universities can work together to develop or multi regional alliances to jointly develop and maintain [6].

\section{Promotions of MOOC resources}

Although MOOC has developed in China for more than two years, many people don't have a very accurate understanding about MOOC. Some people mistakenly think that MOOC is a quality class or video open class. University librarians need to promote the MOOC to enhance the awareness of the MOOC. University Library has a wealth of information resources, human resources and infrastructure, which makes college librarians have the conditions and advantages to promote MOOC [7]. The librarians as a guide to the MOOC campus of the school should participate in the planning, organizing, coordinating and evaluating of the MOOC activities. They have an important role in promoting the MOOC and expanding the influence of the library.

\section{Conclusion}

The development of information technology can promote educational reform and innovation. Network, digital, personalized, lifelong education system is constructed, so as to realize the learning society. MOOC has brought new opportunities for the development of higher education and university libraries as a typical application of modern information technology. University librarians should pay close attention to the development of MOOC, active participation and cooperation, and make clear its role in promoting the continuous progress of University Library and higher education.

\section{Reference}

[1]Smith B, Min E. MOOCs: A Learning Journey[M]// Hybrid Learning and Continuing Education. Springer Berlin Heidelberg, 2013:244-255.

[2]Wang Hong, Ma Dongming. MOOC localization development and its influence on University Library [J]. University library work, 2014 (6): 47 - 44

[4] Li Ye, Sun Shuping. Investigation of the development MOOC and Research on the problem in the domestic universities [J] . Library science research, 2015 (18): 15 - 18, 68

[5] Zhang Y, Fu Z, Liu Q, et al. A Research on MOOC Services of University Libraries -A Case Study of MOOC Service in Northeast Normal University [J]. Research on Library Science, 2014.

[6] Hong R. The Professional Development of University Library's Subject Librarians in the Age of MOOC (Massive Open Online Course)[J]. Sci-Tech Information Development \& Economy, 2014.

[7]Yang J, Yuan Y. A Research on the Practice and Enlightenment of MOOC Services in American University Libraries[J]. Research on Library Science, 2014, 34(5):916.

[8]Hannah Gore. Massive Open Online Courses (MOOCs) and Their Impact on Academic Library Services: Exploring the Issues and Challenges[J]. New Review of Academic Librarianship, 2014, 20(1):4-28. 